\title{
Magnesium and Cardiovascular Disease, a Mini Review
}

\author{
Ana Rosa Cunha*, Bianca Cristina Marques, Jenifer d'El-Rei and Mario Fritsch Neves \\ Department of Clinical Medicine, State University of Rio de Janeiro, Brazil
}

Submission: April 03, 2018; Published: May 30, 2018

*Corresponding author: Ana Rosa Cunha, Department of Clinical Medicine, State University of Rio de Janeiro,Boulevard 28 de setembro, 77 - Vila Isabel, CEP 20551-030, Rio de Janeiro, RJ, Brasil, Email: anarosacunha@gmail.com

\section{Mini Review}

Some studies have shown that a diet rich in minerals such as potassium, calcium and magnesium, present mainly in fruits and vegetables, is associated with lower incidence of cardiovascular disease [1]. In particular, magnesium has been the target of many clinical trials [2], considering that there is a significant inverse correlation between serum magnesium levels and occurrence of cardiovascular events [3]. It has been also demonstrated the association between low magnesium levels and high blood pressure, and in a subgroup of hypertensive female patients on diuretic therapy, magnesium levels are reduced, a phenomenon associated with increased blood pressure, carotid artery remodeling, changes in wave reflection and increased cardiovascular risk [4]. Likewise, lower concentrations of magnesium have been frequently associated with markers of inflammation, oxidative stress, impaired endothelium-dependent vasodilation and low insulin sensitivity $[5,6]$.

A recent meta-analysis with eleven clinical trials, which included more than five hundred participants with follow-up periods ranged from one to six months, showed that the magnesium supplementation resulted in a reduction of systolic and diastolic blood pressure in individuals with insulin resistance, pre diabetes, or other non communicable chronic diseases [7]. Recently, our group evaluated the effects of magnesium supplementation on blood pressure and vascular function in thiazide-treated hypertensive women in a randomized, double-blind, clinical trial. Patients were allocated into placebo or magnesium chelate $(600 \mathrm{mg} /$ day) supplementation group, and were evaluated at baseline and after six months [8]. In this study, there was a significant increase in carotid intima-media thickness in the placebo group, a significant reduction of systolic blood pressure in the magnesium group, and a positive correlation between variation of intracellular magnesium and brachial flow-mediated dilatation. These findings indicated that 6-month magnesium supplementation was able to promote better blood pressure control, improvement of endothelial function and attenuation of subclinical atherosclerosis [8]. According to experimental studies, magnesium deficit is able to promote release of pro-inflammatory cytokines and to stimulate excessive production of free radicals [9].

In fact, deficiency in magnesium dietary intake, supplementation, and/or serum concentration is often associated with low-grade inflammation, a risk factor for hypertension and cardiovascular disease [9]. Some actions of magnesium could reduce the consequences of oxidative stress on the vascular wall, thus inhibiting an increase in the vascular tone [10]. Indeed, it has been demonstrated that magnesium modifies the vascular tone by regulating endothelium and smooth muscle cell functions along with an important role in the classical pathway of nitric oxide (NO) release. The production of prostacyclin and NO seems to be intensified by magnesium, which could be a mechanism to induce vasodilation as shown in animal's studies [11].

Besides its effects on blood pressure, some evidences have shown the influence of magnesium on serum glucose, HDL-cholesterol, and triglycerides levels, which suggest that magnesium, might play an important role in metabolic syndrome. A systematic review published two years ago showed that magnesium supplementation in individuals with hypomagnesemia can be effective in the treatment of metabolic syndrome [12]. In conclusion, magnesium is a mineral with essential functions, and it is important to maintain their appropriate levels. Different findings of studies concerning the effects of magnesium on the vascular system indicate that there are some mechanisms of actions of magnesium that are not well understood. It appears that magnesium is more related to functional vascular changes, involved in local metabolic stability with no influence on the vascular structure. Further studies are needed to evaluate the risk of magnesium deficiency and the cardiovascular benefits of this mineral supplementation.

\section{References}

1. He K, Liu K, Daviglus ML, Morris SJ, Loria CM, et al. (2006) Magnesium intake and incidence of metabolic syndrome among young adults. Circulation 113(13): 1675-1682. 
2. Hatzistavri LS, Sarafidis PA, Georgianos PI, Tziolas IM, Aroditis CP, et al. (2009) Oral magnesium supplementation reduces ambulatory blood pressure in patients with mild hypertension. Am J Hypertens 22(10): 1070-1075

3. Bo S, Pisu E (2008) Role of dietary magnesium in cardiovascular disease prevention, insulin sensitivity and diabetes. Curr Opin Lipidol 19(1): 50-56.

4. Cunha AR, Medeiros F, Umbelino B, Oigman W, Touyz RM, et al. (2013) Altered vascular structure and wave reflection in hypertensive women with low magnesium levels. J Am Soc Hypertens 7(5): 344-352.

5. Mazur A, Maier JA, Rock E, Gueux E, Nowacki W, et al. (2007) Magnesium and the inflammatory response: potential physiopathological implications. Arch Biochem Biophys 458(1): 48-56.

6. Joris PJ, Plat J, Bakker SJ, Mensink RP (2016) Long-term magnesium supplementation improves arterial stiffness in overweight and obese adults: results of a randomized, double-blind, placebo-controlled intervention trial. Am J Clin Nutr 103(5): 1260-1266.

7. Dibaba DT, Xun P, Song Y, Rosanoff A, Shechter M, et al. (2017) The effect of magnesium supplementation on blood pressure in individuals with insulin resistance, prediabetes, or noncommunicable chronic diseases: a meta-analysis of randomized controlled trials. Am J Clin Nutr 106(3): 921-929.

8. Cunha AR, D’El-Rei J, Medeiros F, Umbelino B, Oigman W, et al. (2017) Oral magnesium supplementation improves endothelial function and attenuates subclinical atherosclerosis in thiazide-treated hypertensive women. J Hypertens 35(1): 89-97.

9. Nielsen FH (2018) Magnesium deficiency and increased inflammation: current perspectives. J Inflamm Res 11: 25-34.

10. Laurant P, Touyz RM (2000) Physiological and pathophysiological role of magnesium in the cardiovascular system: implications in hypertension. J Hypertens 18(9): 1177-1191.

11. Northcott C, Watts SW (2004) Low [Mg2+]e enhances arterial spontaneous tone via phosphatidylinositol 3-kinase in DOCA-salt hypertension. Hypertension 43(1): 125-129.

12. Guerrero-Romero F, Jaquez-Chairez FO, Rodríguez-Morán M (2016) Magnesium in metabolic syndrome: a review based on randomized, double-blind clinical trials. Magnes Res 29(4): 146-153.

\section{Your next submission with Juniper Publishers} will reach you the below assets

- Quality Editorial service

- Swift Peer Review

- Reprints availability

- E-prints Service

- Manuscript Podcast for convenient understanding

- Global attainment for your research

- Manuscript accessibility in different formats

( Pdf, E-pub, Full Text, Audio)

- Unceasing customer service

Track the below URL for one-step submission https://juniperpublishers.com/online-submission.php 